
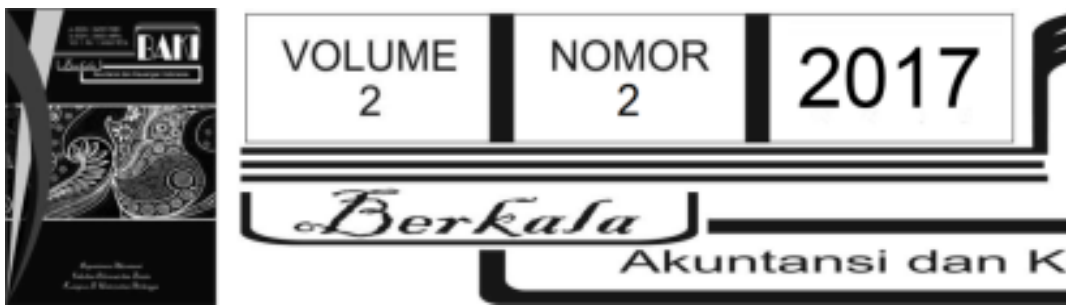

Loerkata

\title{
Pengendalian Internal Sebagai Variabel Moderasi Pada Pengaruh Antara Desentralisasi Terhadap Kinerja Manajerial
}

\author{
Nanik Hidayati ${ }^{1,2}$ \\ Wiwiek Dianawati ${ }^{1}$ \\ ${ }^{1} \mathrm{FEB}$ Universitas Airlangga \\ ²nanikhidayati19@gmail.com
}

\section{INFO ARTIKEL}

Histori Artikel:

Tanggal Masuk 3 Agustus 2017

Tanggal Diterima 18 Agustus

2017

Tersedia Online 30 September 2017

Kata Kunci:

desentralisasi;

pengendalian internal dan kinerja manajerial

\begin{abstract}
A B STRAK
Penelitian ini bertujuan untuk mengetahui apakah tingkat desentralisasi berpengaruh terhadap kinerja manajerial BPS di Jawa Timur serta untuk mengetahui apakah pengendalian internal memperkuat pengaruh tingkat desentralisasi terhadap kinerja manajerial BPS se Jawa Timur. Penelitian ini merupakan penelitian kuantitatif dengan menggunakan metode analisis statistik deskriptif dan analisis regresi dengan variabel moderasi. Data yang digunakan adalah data primer yang diperoleh melalui sensus kepada para Pejabat Pembuat Komitmen pada satuan kerja Badan Pusat Statistik Kabupaten/Kota se Jawa Timur. Variabel yang digunakan dalam penelitian ini yaitu tingkat desentralisasi sebagai variabel independen, efektifitas pengendalian internal sebagai variabel moderator dan kinerja manajerial sebagai variabel dependen. Hasil penelitian menyatakan bahwa desentralisasi tidak berpengaruh terhadap kinerja manajerial meskipun arahnya sudah sesuai dengan yang diprediksikan. Selain itu pengendalian internal juga tidak memperkuat pengaruh desentralisasi terhadap kinerja manajerial meskipun arahnya sudah sesuai dengan yang diprediksikan.
\end{abstract}

\section{Pendahuluan}

Pada tahun 2003-2004, pemerintah Indonesia telah melakukan reformasi keuangan negara dengan diterbitkan satu paket Undang-Undang di bidang keuangan negara yang terdiri dari UU Nomor 17 Tahun 2003, UU Nomor 1 Tahun 2004, dan UU Nomor 15 Tahun 2004 yang menyebabkan perubahan fungsi, yaitu dari fungsi Financial Administration ke fungsi Public Financial Management. Dalam rangka pelaksanaan Anggaran Pendapatan dan Belanja Negara (APBN), maka diterbitkanlah Peraturan Menteri Keuangan (PMK) No. 190/PMK.05/2012 
tentang tata cara pembayaran dalam rangka pelaksanaan APBN, yang memberi kewenangan dan keleluasan secara nyata dan bertanggungjawab kepada setiap satuan kerja untuk mengelola keuangan negara sehingga mekanisme pelaksanaan anggaran menjadi lebih sederhana dan diharapkan bisa memperlancar pencairan anggaran.

Untuk meningkatkan kinerja maka salah satu upaya yang dilakukan adalah memperkuat sistem pengendalian internal. Hal ini karena sistem pengendalian internal memegang peran yang sangat penting terutama dalam mengelola keuangan negara. Dengan demikian keuangan negara dapat dipergunakan secara transparan, efektif dan efisien

Menurut Mardiasmo (2002: 214), adanya pemberian kewenangan dan keleluasaan dalam mengelola keuangan negara, agar tidak terjadi penyimpangan dan penyelewengan, maka dalam pemberian kewenangan dan keleluasaan tersebut harus diikuti dengan pengawasan dan pengendalian yang kuat. Penguatan fungsi pengendalian dilakukan dengan melalui pembuatan sistem pengendalian intern yang efektif serta pemberdayaan auditor internal pemerintah misalnya inspektorat

Hasil penelitian Hidayat (2015), Ingkiriwang (2013) dan Nadirsyah et al. (2012) mkenunjukan bahwa tingkat desentralisasi berpengaruh signifikan terhadap kinerja manajerial. Akan tetapi terjadi sebaliknya terhadap penelitian yang dilakukan oleh Miah dan Mia (1996) yang menyatakan bahwa tingkat desentralisasi tidak berpengaruh terhadap kinerja manajerial. Hasil penelitian Nugraha dan Astha (2016) dan Primadana et al. (2014) membuktikan pengawasan internal sebagai variabel moderasi pada pengaruh tingkat desentralisasi terhadap kinerja manjerial.

Objek pada penelitian ini adalah tingkat desentralisasi, efektifitas pengendalian internal dan kinerja manajerial. Sedangkan subyeknya adalah para Pejabat Pembuat Komitmen di Badan Pusat Statistik se Jawa Timur oleh karena Badan Pusat Statistik pada tahun 2017 terpilih sebagai salah satu Kementerian/Lembaga (K/L) yang telah terbukti mengelola keuangan khususnya Anggaran Pendapatan dan Belanja Negara (APBN) dengan baik pada tahun anggaran 2016, yang mana pemberian penghargaan tersebut berdasarkan kinerja $\mathrm{K} / \mathrm{L}$ yang merupakan penjabaran dari evaluasi aspek kesesuaian, aspek kepatuhan terhadap perundangundangan dan aspek efisiensi pelaksanaan kegiatan (Objek pada penelitian ini adalah tingkat desentralisasi, pengendalian internal dan kinerja manajerial. Sedangkan subyeknya adalah para Pejabat Pembuat Komitmen di Badan Pusat Statistik se Jawa Timur oleh karena Badan Pusat Statistik pada tahun 2017 terpilih sebagai salah satu Kementerian/Lembaga (K/L) yang telah terbukti mengelola keuangan khususnya Anggaran Pendapatan dan Belanja Negara (APBN) dengan baik pada tahun anggaran 2016, yang mana pemberian penghargaan tersebut berdasarkan kinerja $\mathrm{K} / \mathrm{L}$ yang merupakan penjabaran dari evaluasi aspek kesesuaian, aspek kepatuhan terhadap perundang-undangan dan aspek efisiensi pelaksanaan kegiatan. 
Perbedaan penelitian ini dengan penelitian sebelumnya adalah (1) adanya peraturan yang memberikan kewenangan dan keleluasaan bagi satuan kerja untuk mengelola keuangan negara (APBN) dan pendelegasian kewenangan kepada manajer yang lebih rendah yaitu Pejabat Pembuat Komitmen (PPK) dalam melakukan tindakan yang mengakibatkan pengeluaran anggaran, (2) Penelitian sebelumnya dilakukan di sektor swasta (Ingkiriwang 2013) dan lingkungan Pemerintah Daerah (Nadirsyah et.al., 2012; Samadara 2016; Miah dan Mia 1996), sedangkan pada penelitian ini dilakukan pada lingkungan Pemerintah Pusat khususnya instansi vertikal yang mempunyai tanggungjawab langsung kepada Presiden, (3) Instrumen penelitian untuk mengukur variabel pengendalian internal menggunakan instrumen dari Badan Pengawasan Keuangan dan Pembangunan (BPKP) yang salah satu tugas pokok dan fungsi sebagai pembina, pembimbing dan pelaksana konsultasi dalam penyelenggaraan Sistem Pengendalian Intern Pemerintah (SPIP) di wilayah kerjanya pada instansi pemerintah pusat, pemerintah daerah dan badan-badan yang mempunyai kepentingan keuangan atau kepentingan lain dari Pemerintah Pusat dan/atau Pemerintah Daerah, (4) Sedangkan instrumen penelitian untuk mengukur variabel tingkat desentralisasi merupakan penyesuaian dari tugas dan kewenangan dari Pejabat Pembuat Komitmen yang tertulis dalam PMK190/PMK05/2012 dan Peraturan Presiden 70 tahun 2012.

Fokus penelitian ini adalah untuk menyelidiki pengaruh interaksi tingkat desentralisasi dan efektifitas pengendalian internal terhadap kinerja manajerial Pejabat Pembuat Komitmen pada BPS se-Jawa Timur atas pertimbangan BPS se-Provinsi Jawa Timur mempunyai anggaran terbesar dibandingkan dengan BPS provinsi lainnya.

\section{Tinjauan Pustaka}

\subsection{Teori Contigency}

Pendekatan teori contingency merupakan perkembangan penting dalam teori akuntansi manajemen yang membutuhkan kejelasan konseptual dan penggunaan metodologi penelitian. Pertama, konsep utama dari pendekatan kontijensi dengan mempertimbangkan beberapa situasi dimana teori kontinjensi telah muncul dari interpretasi data penelitian. Kedua teori contingency akuntansi manajemen baik empiris maupun teoritis, diuraikan dan dinilai dengan mengacu pada kerangka kerja sesuai dengan pespektif kontrol organisasi.

Pendekatan contingency untuk akuntansi manajemen didasarkan pada premis bahwa tidak ada yang sesuai universal yang berlaku sama untuk semua organisasi dalam segala situasi. Sebaliknya disarankan untuk bergantung pada keadaan tertentu dimana sebuah organisasi menemukan dirinya. Dengan demikian teori contingency harus mengidentifikasikan aspek-aspek tertentu yang berhubungan dengan keadaan tertentu yang telah ditentukan yang 
menunjukkan suatu pencocokan yang tepat. Pada penelitian ini menggambarkan pengaruh dari tingkat desentralisasi terhadap kinerja manajerial. Ada bukti yang menunjukkan bahwa desentralisasi mempengaruhi cara dimana informasi anggaran paling baik digunakan dan cenderung mengarah kepada kinerja organisasi yang lebih efektif. Akan tetapi sebuah studi berikutnya dengan menggunakan langkah-langkah yang sama tidak menghasilkan hubungan tersebut, dimana gaya yang kaku lebih cenderung mengarah ke kinerja yang lebih baik daripada gaya yang fleksibel. Tetapi perbandingan dari dua penelitian tersebut menunjukkan perbedaan situasional penting yang sugestif dari penjelasan contingency (Otley 1980)

\subsection{Teori $X$ dan Teori $Y$}

Menurut McGregor (1989) konsep konvensional tentang tugas manajemen dalam memanfaatkan energi manusia dalam sebuah organisasi dinyatakan dalam tiga proposisi yang disebut dengan Teori $\mathrm{X}$, yaitu:

1. Manajemen bertanggungjawab mengatur unsur-unsur usaha produktif yaitu uang, bahan, peralatan dan orang untuk kepentingan ekonomi.

2. Sehubungan dengan orang, prosesnya adalah mengarahkan, memotivasi, mengendalikan dan memodifikasi perilaku mereka agar sesuai dengan dengan kebutuhan organisasi.

3. Jika tidak ada intervensi aktif dari manajemen, maka orang akan bersikap pasif. Oleh karena itu mereka harus dibujuk, diberi penghargaan, dihukumdan dikontrol agar dapat diarahkan. Itu semua merupakan tugas manajemen dalam mengelola manager atau pekerja bawahan. Dibalik teori konvensional tersebut terdapat beberapa keyakinan tambahan yaitu:

4. Rata-rata manusia bekerja sesedikit mungkin.

5. Manusia tidak mempunyai ambisi, tidak menyukai tanggungjawab dan lebih memilih untuk dipimpin.

6. Manusia pada dasarnya egois, acuh tak acuh terhadap kebutuhan organisasi.

7. Manusia secara alami resisten terhadap perubahan.

8. Manusia mudah tertipu, tidak jujur dan siap menipu.

Pendekatan konvensional teori $\mathrm{X}$ ini dianggap tidak memadai sehubungan dengan munculnya temuan ilmu sosial yang baru. Menurut ilmu sosial tingkah laku manusia bukanlah konsekuensi dari kondisi alaminya namun lebih kepada akibat dari perilaku organisasi, filosofi, kebijakan dan praktek manajemen. Secara garis besar teori $\mathrm{X}$ belum memperhatikan asal suatu motivasi yakni kebutuhan fisiologis, kebutuhan rasa aman, kebutuhan untuk berinteraksi dengan orang lain/sosial, kebutuhan akan harga diri dan kebutuhan pemenuhan diri sendiri. Berdasarkan kekurangan ini maka muncullah teori $Y$ yang diusulkan oleh Douglas McGregor yang mengasumsikan tentang sifat manusia, yaitu: 
1. Manajemen bertanggungjawab untuk mengatur usaha-usaha produktif misal uang, bahan, peralatan dan manusia untuk kepentingan ekonomi.

2. Manusia tidak pasif atau resisten terhadap kebutuhan organisasi sebagai hasil dari pengalaman dalam organisasi.

3. Motivasi, potensi untuk berkembang, tanggungjawab merupakan persiapan untuk mengarahkan perilaku menuju tujuan organisasi yang ada pada diri manusia. Merupakan tanggungjawab manajemen untuk mengenalkan manusia dan mengembangkan karakteristik manusia untuk diri mereka sendiri.

4. Tugas utama manajemen adalah mengatur kondisi organisasi dan metode operasi sehingga seseorang bisa mencapai cita-cita terbaiknya dengan mengarahkan usaha mereka sendiri menuju tujuan organisasi. Hal ini merupakan proses untuk menciptakan peluang, melepaskan potensi, menghilangkan hambatan, mendorong pertumbuhan, dan memberikan panduan, seperti telah disebut oleh Peter Drucker sebagai "manajemen untuk tujuan" yang berbeda dengan "manajemen oleh kontrol". McGregor menambahkan bahwa hal itu tidak melibatkan pelepasan manajemen, tidak adanya kepemimpinan, penurunan standar atau karakteristik lainnya yang berhubungan dengan pendekatan "lunak" dibawah teori $X$

Perbedaan teori $\mathrm{X}$ dan $\mathrm{Y}$ adalah bahwa teori $\mathrm{X}$ menempatkan ketergantungan pada kontrol eksternal pada perilaku manusia, sedangkan teori $Y$ bergantung pada pengendalian diri dan mengarahkan diri sendiri. Perbedaan ini merupakan perbedaan dalam memperlakukan manusia sebagai anak-anak dan memperlakukan manusia sebagai orang dewasa. Gagasan inovatis McGregor yang sepenuhnya konsisten dengan teori $Y$ dan telah diterapkan sampai sekarang dengan berhasil adalah adanya desentralisasi dan delegasi.

\subsection{Desentralisasi}

Menurut Mulyadi (2001: 378), desentralisasi merupakan pendelegasian kebebasan dalam mengambil keputusan dari manajer puncak kepada para manajer yang lebih rendah. Semakin besar kebebasan dalam mengambil keputusan maka tingkat desentralisasinya semakin besar dan sebaliknya. Sedangkan menurut Miah dan Mia (1996) delegasi menyediakan manajemen yang lebih rendah dengan otoritas dalam mengambil keputusan yang disertai dengan tanggung jawab atas tindakan mereka. Otoritas merupakan diskresioner untuk melaksanakan tugas, sedang tanggung jawab adalah kewajiban dalam mencapai tugas tersebut. Pentingnya desentralisasi sebagai unsur struktural formal yang telah lama ditekankan dalam organisasi dan manajemen. Adanya peningkatan adminnistrasi yang komplek, tugas dan tanggungjawab harus didelegasikan pada manajer yang lebih rendah agar beban pengambilan pada manajer puncak menjadi lebih ringan. Sedangkan menurut Miah dan Mia (1996) delegasi menyediakan manajemen yang lebih rendah dengan otoritas dalam mengambil keputusan yang 
disertai dengan tanggung jawab atas tindakan mereka. Otoritas merupakan diskresioner untuk melaksanakan tugas, sedang tanggung jawab adalah kewajiban dalam mencapai tugas tersebut. Pentingnya desentralisasi sebagai unsur struktural formal yang telah lama ditekankan dalam organisasi dan manajemen. Adanya peningkatan adminnistrasi yang komplek, tugas dan tanggungjawab harus didelegasikan pada manajer yang lebih rendah agar beban pengambilan pada manajer puncak menjadi lebih ringan.

\subsection{Pengendalian Internal}

Menurut Arens et al. (2008: 370), sistem pengendalian internal terdiri atas kebijakan dan prosedur yang dirancang untuk memberikan manajemen kepastian yang layak bahwa suatu organisasi telah mencapai tujuan dan sasarannya. Kebijakan dan prosedur tersebut sering disebut pengendalian dan secara kolektif membentuk pengendalian internal.

Undang-undang keuangan Negara, khususnya Undang-undang Nomor 1 Tahun 2004 tentang Perbendaharaan Negara, memberi dampak akan perlunya sistem pengelolaan keuangan negara yang efektif dan efisien. Hal ini baru dapat dicapai jika seluruh tingkat pimpinan menyelenggarakan kegiatan pengendalian internal atas keseluruhan kegiatan di satuan kerja masing-masing.

Dalam PP No 60 tahun 2008 dijelaskan bahwa Pengendalian Internal adalah proses yang integral pada tindakan dan kegiatan yang dilakukansecara terus menerus oleh pimpinan dan seluruh pegawai untuk memberikan keyakinan memadaiatas tercapainya tujuan organisasi melalui kegiatanyang efektif dan efisien, keandalan pelaporankeuangan, pengamanan aset negara, dan ketaatanterhadap peraturan perundang-undangan.Pengendalian inernal tersebut dilakukan dengan berpedoman Sistem Pengendalian Internal Pemerintah (SPIP) yaitu sistem pengendalian internal yang diselenggarakan secara menyeluruh pada lingkungan pemerintah pusat dan daerah.

Sistem Pengendalian Intern Pemerintah (SPIP) yang diatur dengan jelas dalam PP No 60 tahun 2008 merupakan adopsi dari The Committee of Sponsoring Organization of the Treadway Commission (COSO), dimana komponen-komponennya terdiri dari lingkungan pengendalian, penilaian risiko, kegiatan pengendalian, informasi dan komunikasi, dan pemantauan pengendalian intern.

\subsection{Kinerja Manajerial}

Kinerja didefinisikan sebagai sejauh mana tujuan yang telah ditetapkan oleh organisasi tersebut dapat tercapai. Dan kinerja manajerial dari sebuah organisasi dapat digunakan untuk 
menilai kinerja. Termasuk tujuan pemerintah adalah pertumbuhan ekonomi, stabilitas harga, kesejahteraan sosial dan pendidikan (Miah dan Mia 1996).

Menurut Mahoney et al. (1963) kinerja manajerial merupakan tingkat keberhasilan pencapaian peran manajerial, yang dapat diukur dari perencanaan, investigasi, koordinasi, evaluasi, pengawasan, pengaturan staf, negosiasi dan representasi serta kinerja secara keseluruhan. Kinerja manajerial yang dihasilkan dari para manajer adalah salah satu indikator yang bisa digunakan untuk meningatkan efektifitas sebuah organisasi.

\subsection{Kerangka Konseptual}

Penelitian ini mengidentifkasi satu variabel independen yaitu tingkat desentralisasi, satu variabel moderasi yaitu efektifitas pengendalian internal yang diperkirakan akan berpengaruh terhadap satu variabel dependen yaitu kinerja manajerial. Secara ringkas kerangka konseptual dapat dilihat di gambar 1 berikut.

\section{Gambar 1. Kerangka Konseptual}

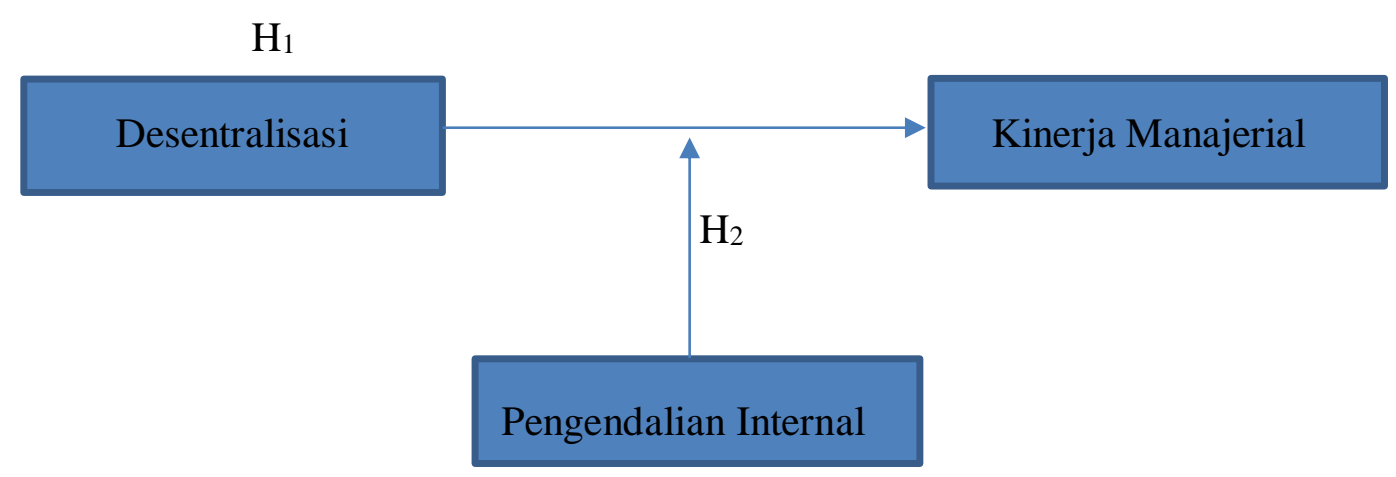

Dari gambar 1 kerangka konseptual diatas dapat dijelaskan bahwa tingkat desentralisasi diharapkan akan berpengaruh positif terhadap kinerja manajerial. Hal ini merujuk pada teori $X$ dan $Y$ yang dikemukakan oleh Douglas McGregor dimana tugas manajemen adalah untuk mendesain organisasi serta memotivasi pegawai dengan memberi kesempatan mengembangkan potensi masing-masing individu dan akhirnya memberikan kewenangan dengan mengikutsertakan bawahan atau manajer yang lebih rendah membuat keputusan untuk mencapai tujuan organisasi. Selanjutnya efektifitas pengendalian internal dapat memperkuat pengaruh tingkat desentralisasi terhadap kinerja manajerial satuan kerja, yang dapat diprediksi sebagai berikut.

1. Semakin tinggi/rendah tingkat desentralisasi maka akan semakin tinggi/rendah kinerja manajerial. Atau dengan kata lain, tinggi rendahnya kinerja manajerial dipengaruhi oleh tinggi rendahnya tingkat desentralisasi. 
2. Efektifitas pengendalian internal diharapkan dapat memperkuat pengaruh tingkat desentralisasi terhadap kinerja manajerial.

\subsection{Pengembangan Hipotesis Dan Analisis}

\subsubsection{Hubungan Desentralisasi dan Kinerja Manajerial}

Garrison et al. (2013: 66) menyatakan bahwa dengan menggunakan desentralisasi yaitu mendelegasikan kewenangan dalam mengambil keputusan pada manajer yang lebih rendah,seringkali akan meningkatkan motivasi mereka sehingga dapat meningkatkan keputusan kerja juga tigkat retensi karyawan, serta kinerja yang membaik. Mulyadi (2001: 380381) menunjukkan bahwa dengan adanya kebebasan dalam mengambil keputusan berakibat bisa merasakan status lebih tinggi jika dibandingkan dengan mereka yang tidak mempunyai kebebasan mengambil keputusan, sehingga dapat memotivasi manajer lebih rendah untuk terus berprestasi. Miah dan Mia (1996) berpendapat bahwa kinerja cenderung meningkat dengan peningkatan desentralisasi dalam pengambilan keputusan di tingkat kabupaten. Sedangkan menurut Hill (1988), dalam organisasi yang besar dan komplek, tanggungjawab dan pengambilan keputusan secara sentralisasi dapat menyebabkan informasi yang berlebihan, pertanggungjawaban dan kontrol menjadi kabur dan berakibat pada keputusan perusahaan yang buruk. Di sisi lain desentralisasi dinyatakan sebagai pusat keuntungan dalam sebuah organisasi, sehingga peneliti seperti Williamson $(1970,1975)$ menyatakan bahwa adanya pusat keuntungan dalam mencapai efisiensi (meminimalkan biaya). Dalam oganisasi pemerintah, biaya yang minimal sangat penting dalam rangka biaya penyediaan layanan yang efektif kepada masyarakat. Berdasarkan uraian diatas maka dirumuskan hipotesis yaang pertama, yaitu:

\section{$\mathrm{H}_{1}$ : Tingkat desentralisasi berpengaruh positif terhadap kinerja manajerial.}

\subsubsection{Hubungan Desentralisasi, Pengendalian Internal dan Kinerja Manajerial}

Miah dan Mia (1996) menyatakan bahwa dalam situasi pengambilan keputusan yang desentralisasi, manajer bawahan memegang peran dalam membuat keputusan dan menerapkan keputusannya sehingga manajer menjadi bertanggungjawab pada operasi sub unit. Situasi seperti itu mengarah pada penggunaan informasi yang lebih besar, akibatnya ada kebutuhan yang besar untuk menggunakan sistem kontrol akuntansi. Menurut Mardiasmo (2002: 214), pemberian kewenangan dan keleluasaan dalam mengelola keuangan negara, agar tidak terjadi penyimpangan dan penyelewengan, maka dalam pemberian kewenangan dan keleluasaan tersebut harus diikuti dengan pengawasan dan pengendalian yang kuat. 
Penguatan fungsi pengendalian dilakukan dengan melalui pembuatan sistem pengendalian intern yang efektif serta pemberdayaan auditor internal pemerintah. Sejalan dengan pendapat Mardiasmo tersebut, maka penelitian yang dilakukan oleh Primadana et al. (2014) dan Nugraha dan Astha (2016) menemukan bahwa pengawasan internal berhasil memoderasi pengaruh desentralisasi terhadap kinerja manajerial.

Pemberlakuan desentralisasi di bidang keuangan pada organisasi pemerintah khususnya pemerintah pusat semakin nyata setelah dikeluarkannya PMK No 190/PMK.05/2012 tentang tatacara pembayaran dalam rangka pelaksanaan APBN yang berlaku sejak 1 Januari 2013 sebagai pengganti dari PMK yang lama yaitu PMK Nomor 134/PMK.06/2005. Pemberlakukan PMK No 190/PMK.05/2012 memberi kewenangan dan keleluasan secara nyata dan tanggungjawab kepada setiap satker untuk mengelola keuangan negara tanpa ada jaminan adanya kesalahan atau penyelewengan. Untuk menghindari kesalahan ataupun penyelewengan maka dibutuhkan sistem pengendalian internal oleh karena sistem pengendalian internal mempunyai peran yang sangat penting dalam rangka mengelola keuangan negara yang transparan, efektif dan efisien. Berdasarkan pendapat diatas, maka disusun hipotesis kedua sebagai berikut.

\section{$\mathrm{H}_{2}$ : Pengendalian internal memperkuat pengaruh tingkat desentralisasi terhadap kinerja manajerial.}

\section{Metodologi Penelitian}

Penelitian ini merupakan penelitian kuantitatif dengan mengguna metode analisis statistic deskriftif dan analisis regresi dengan variabel moderasi. Data yang digunakan adalah data primer yang diperoleh melalui sensus kepada para Pejabat Pembuat Komitmen pada satker BPS se Jawa Timur. Penelitian ini menggunakan pertanyaan tertutup menggunakan skala Likert 1-5 untuk variabel independen, variabel moderasi dan variabel independen. Variabel-variabel yang digunakan dalam penelitian ini adalah:

(a) Tingkat desentralisasi sebagai variabel bebas $(X)$

(b) Efektifitas pengendalian internal sebagai variabel moderator (M)

(c) Kinerja manajerial sebagai variabel terikat $(\mathrm{Y})$

Populasi pada penelitian ini adalah Pejabat Pembuat Komitmen pada BPS se Jawa Timur yaitu sebanyak 38 PPK. Adanya proses mutasi pegawai di lingkungan BPS Jawa Timur mengakibatkan satu PPK dipindahkan dan belum ada pengganti PPK yang baru, sehingga populasi pada penelitian ini menjadi 37 PPK.Semua anggota populasi dijadikan sampel (sensus).

Untuk menjamin efektifitas dalam mengumpulkan data, maka kuesioner dikirim via email dan disampaikan secara langsung kepada responden. Pengiriman email melalui email kantor 
BPS se Jawa Timur dan email pribadi dari masing-masing Pejabat Pembuat Komitmen. Peneliti juga mengkonfirmasi masing-masing Pejabat Pembuat Komitmen yang menjadi responden melalui telepon untuk memastikan bahwa email telah diterima oleh Pejabat Pembuat Komitmen sehingga responden memberi jawaban dengan memberi tanda pada jawaban yang disediakan. Penelitian ini akan menguji hipotesis yang telah diajukan dengan menggunakan bantuan Statistical Product and Service Solution (SPSS) versi 20. Hipotesis H1 diuji dengan melakukan analisis regresi sederhana yang persamaannya adalah:

$\mathrm{Y}=\mathrm{a}+\mathrm{b}_{1} \mathrm{X}+\mathrm{e}($ persamaan 1$)$

Sedangkan $\mathrm{H} 2$ diuji dengan Moderated Regression Analysis (MRA) yang persamaannya adalah:

$\mathrm{Y}=\mathrm{a}+\mathrm{b}_{2} \mathrm{X}+\mathrm{b}_{3} \mathrm{M}+\mathrm{e}($ persamaan 2$)$

$Y=a+b_{4} X+b_{5} M+b_{6} X^{*} M+e$ (persamaan 3)

Kriteria pengujian hipotesis adalah dengan membandingkan nilai probabilitas signifikansinya (p) yang dapat diperoleh dari perhitungan SPSS dengan nilai a (tingkat kesalahan) yang ditetapkan. Jika nilai probabilitas signifikansinya lebih kecil dari $\alpha$ yang ditetapkan maka $\mathrm{H}_{0}$ dapat ditolak (Ghozali, 2006:84-85)

\section{Analisis dan Pembahasan}

Pada penelitian ini diperoleh rata-rata score jawaban responden terhadap variabel kinerja manajerial sebesar 3,7 (interval 2,37 sampai dengan 4,41). Dapat disimpulkan bahwa kinerja manajerial Pejabat Pembuat Komitmen di BPS se Jawa Timur pada kategori sedang. Hal ini dapat dilihat pada jawaban responden baik dari Pejabat Pembuat Komitmen, Kuasa Pengguna Anggaran maupun Pejabat Penandatangan SPM sebagaian besar menjawab netral dan setuju sembilan butir pertanyaan sehubungan dengan kinerja dari Pejabat Pembuat Komitmen

Rata-rata score jawaban responden terhadap variabel tingkat desentralisasi sebesar 3,75 (interval 2,6 sampai dengan 4,5). Dapat disimpulkan bahwa tingkat desentralisasi yang dimiliki oleh Pejabat Pembuat Komitmen dalam mengelola keuangan di BPS se Jawa Timur pada kategori sedang atau tergantung perintah. Hal ini dapat dilihat pada jawaban responden sebagaian besar menjawab tergantung perintah dan tingkat wewenang dengan pertimbangan atas enam butir pertanyaan sehubungan dengan tingkat desentralisasi.

Rata-rata score jawaban responden terhadap variabel efektifitas pengendalian internal sebesar 3,95 (interval 3,06 sampai dengan 4,85). Dapat disimpulkan bahwa efektifitas pengendalian internal yang ada di BPS se Jawa Timur pada kategori sedang. Hal ini dapat dilihat pada jawaban responden sebagaian besar menjawab kadang-kadang dan sering atas enam puluh sembilan butir pertanyaan sehubungan dengan efektifitas pengendalian internal. 


\subsection{Pengujian Validitas dan Reliabilitas}

Dari perhitungan dengan SPSS diperoleh nilai probabilitas untuk korelasi pada masingmasing pertanyaan untuk variabel tingkat desentralisasi lebih kecil dari 0,05 serta memiliki Cronbach Alpha lebih besar 0,6.yaitu sebesar 0,650, sehingga item pertanyaan untuk variabel tingkat desentralisasi $(X)$ valid dan reliabel untuk pengujian selanjutnya. Untuk variabel pengendalian internal juga memiliki nilai probabilitas untuk korelasi lebih kecil dari 0,05 kecuali untuk item pertanyaan $M_{13}, M_{24}, M_{37}, M_{39}, M_{47}, M_{49}, M_{62}$ yang mempunyai probabilitasnya lebih besar dari 0,05 yaitu $0,067,0,074,0,058,0,151,0,052,0,051,0,174$. Selanjutnya $M_{13}, M_{24}$, $M_{37}, M_{39}, M_{47}, M_{49}, M_{62}$ ini tidak diikutkan dalam pengujian selanjutnya. Sedangkan nilai Cronbach Alpha tanpa mengikutsertakan $M_{13}, M_{24}, M_{37}, M_{39}, M_{47}, M_{49}, M_{62}$ adalah sebesar 0,970 , sehingga item pertanyaan untuk variabel pengendalian internal valid dan reliabel untuk pengujian selanjutnya. Sedangkan variabel kinerja manjerial memiliki nilai probabilitas untuk korelasi lebih kecil dari 0,05 yaitu sebesar 0,000 serta memiliki Cronbach Alpha lebih besar 0,6.yaitu sebesar 0,870 , sehingga item pertanyaan untuk variabel kinerja manajerial $(Y)$ valid dan reliabel untuk pengujian selanjutnya.

\subsection{Pengujian Normalitas}

Uji normalitas dengan Kolmogorov Smirnov test menggunakan kaidah keputusan apabila $\mathrm{p}$ value $>0,05$ (taraf kesalahan) dapat dikatakan data berdistribusi normal. Berikut ini merupakan hasil perhitungan Kolmogorov Smirnov test:

Tabel 1. Hasil analisis Uji Normalitas

\begin{tabular}{|l|l|l|l|l|}
\hline \multicolumn{1}{|c|}{ Variabel } & Positif & Negatif & \multicolumn{1}{|c|}{ K-S Z } & $\begin{array}{c}\text { 2 tailed } \\
\mathbf{p .}^{* *}\end{array}$ \\
\hline Pers 1 & 0,071 & $-0,146$ & 0,885 & 0,413 \\
\hline Pers 2 & 0,073 & $-0,157$ & 0,953 & 0,323 \\
\hline Pers 3 & 0,064 & $-0,124$ & 0,755 & 0,649 \\
\hline
\end{tabular}

Berdasarkan hasil analisis uji normalitas, diperoleh $\mathrm{p}$-value residualnya semuanya lebih besar dari $0,05(\alpha=5 \%)$ sehingga dapat disimpulkan bahwa model berdistribusi normal dan dapat dilakukan regresi dengan Model Regresi Linier Berganda. 


\subsection{Pengujian Heterokedastisitas}

Untuk mendeteksi ada tidaknya heterokedastisitas, salah satu cara yang digunakan adalah dengan uji Glejser. Pada uji Glejser ini meregresikan antara nilai absolut residual dengan variabel independen. Apabila $p$ value $<0,05$ maka terjadi heterokedastisitas dan sebaliknya apabila $p$ value $>0,05$ maka terjadi homoskedastisitas. Berikut merupakan hasil perhitungan uji Glejser:

Tabel 2. Hasil Analisis Uji Heterokedastisitas

\begin{tabular}{|l|c|c|c|c|c|c|}
\hline \multirow{2}{*}{ Variabel } & \multicolumn{2}{|c|}{ Pers (1) } & \multicolumn{2}{c|}{ Pers (2) } & \multicolumn{2}{c|}{ Pers (3) } \\
\cline { 2 - 7 } & T hit & Sig & T hit & Sig & T hit & Sig \\
\hline Desentralisasi (X) & $-1,081$ & 0,287 & $-1,042$ & 0,305 & 0,097 & 0,923 \\
\hline Pengendalian Internal (M) & & & $-1,131$ & 0,266 & 0,066 & 0,948 \\
\hline Interaksi $\mathrm{X}^{\star} \mathrm{M}$ & & & & & $-0,162$ & 0,872 \\
\hline
\end{tabular}

Berdasarkan hasil analisis uji heterokedastisitas dapat diperoleh p-value semuanya > $0,05(\alpha=5 \%)$ dan dapat disimpulkan bahwa tidak terjadi heterokedastisias antara desentralisasi dan pengendalian internal terhadap absolut residualnya.

\subsection{Pengujian Autokorelasi}

Untuk mendeteksi ada tidaknya autokorelasi maka digunakan uji Durbin-Watson (DW test) dengan hipotesis sebagai berikut:

$\mathrm{H}_{0} \quad$ : $\quad$ tidak terdapat autokorelasi $(r=0)$

$\mathrm{H}_{1} \quad$ : $\quad$ terdapat autokorelasi $(r \neq 0)$

Hasil dari perhitungan uji Darbin Watson dapat dilihat pada tabel 4.10 sebagai berikut:

Tabel 3. Hasil Analisis UjiAutokorelasi

\begin{tabular}{|l|c|c|c|c|c|c|c|}
\hline No & & $\mathbf{d l}$ & $\mathbf{d u}$ & $\mathbf{4 - d u}$ & $\mathbf{4 - d l}$ & $\mathbf{d w}$ & Kesimpulan \\
\hline 1 & Pers (1) & 1,419 & 1,530 & 2,470 & 2,581 & 1.829 & Tidak ada autokorelasi \\
\hline 2 & Pers (2) & 1,364 & 1,590 & 2,410 & 2,636 & 1.834 & Tidak ada autokorelasi \\
\hline 3 & Pers (3) & 1,307 & 1,655 & 2,345 & 2,693 & 1.882 & Tidak ada autokorelasi \\
\hline
\end{tabular}

Berdasarkan tabel 3 dapat diketahui bahwa nilai $d w$ pada tiap-tiap persamaan lebih besar dari nilai du dan kurang dari nilai (4-du) sehingga dapat dismpulkan bahwa HO gagal ditolak yang artinya tidak terdapat autokorelasi positif ataupun negatif. 


\subsection{Pengujian Hipotesis Pertama}

Tabel 4. Hasil Regresi Desentralisasi

\begin{tabular}{|l|l|l|l|l|}
\hline \multicolumn{1}{|c|}{ Variabel } & $\begin{array}{l}\text { Unstandardized } \\
\text { Coefficients (B) }\end{array}$ & t hitung & Sig. & Keterangan \\
\hline (Constant) & 30,993 & & & \\
\hline Desentralisasi & 0,090 & 0.404 & 0,689 & Tidak Signifikan \\
\hline R & $=0.068$ & \\
R Square & $=0.005$ & \\
F hitung & $=0.163$ & \\
F tabel & $=4,08$ & \\
Sign. F & $=0.689$ \\
$\alpha$ & $=0.05$ \\
\hline
\end{tabular}

Keterangan : - Jumlah data (observasi) $=37$

- Nilai $\mathrm{T}_{\text {tabel }} \alpha=5 \%=1.984$

- Dependent Variabel X

Hasil pengujian regresi pada tabel 4 tidak berhasil mendukung hipotesis 1 yang berarti tingkat desentralisasi tidak berpengaruh terhadap kinerja manajerial meskipun arahnya sudah sesuai dengan yang diprediksikan. Hal ini dapat dilihat dari $p$ value $=0,689$ yang lebih besar dari nilai $\alpha$ yang ditetapkan $(\alpha=0,05)$.

Selain itu diperoleh nilai $R^{2}=0,005$ yang artinya variasi nilai kinerja manajerial $(Y)$ yang dapat dijelaskan persamaan regresi sebesar $0,5 \%$ dan selebihnya yaitu sebesar 99,5\% dijelaskan oleh variabel lain diluar model regresi tersebut.

\subsection{Pengujian Hipotesis Kedua}

Hasil pengujian regresi berganda dengan pengendalian internal sebagai variabel moderating seperti tampak pada tabel 5 berikut.

Tabel 5. Hasil Regresi Berganda: Pengendalian Internal Sebagai Variabel Moderasi

\begin{tabular}{|l|r|c|c|c|}
\hline \multirow{2}{*}{ Hipotesis } & Persamaan Regresi & $\begin{array}{c}\text { Nilai } \\
\text { F }\end{array}$ & R & $\mathbf{R}^{2}$ \\
\hline $\mathrm{H}_{2}$ & $\mathrm{Y}=29,157+0.085 \mathrm{X}+0.007 \mathrm{M}$ & 0,139 & 0.008 & 0.090 \\
& $(0,375)(0,344)$ & & & \\
& $(0.710)(0.733)$ & & & \\
\hline
\end{tabular}




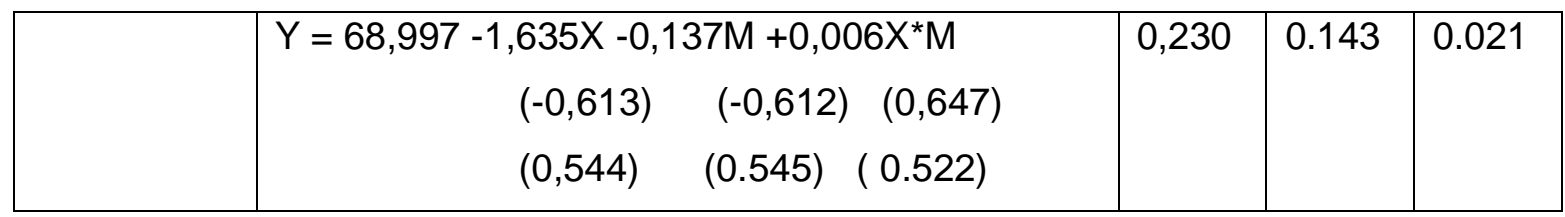

Sumber data : Data primer yang diolah

Keterangan : - Jumlah data (observasi) $=37$

- $\quad$ Nilai $\mathrm{T}_{\text {tabel }} \alpha=5 \%=1.984$

- $\quad$ Nilai $\mathrm{F}_{\text {tabel }} \alpha=5 \%=2.695$

- $\quad$ Dependent Variabel kinerja manajerial $(Y)$

Hasil pengujian regresi pada tabel 5 tidak berhasil mendukung hipotesis 2 yang berarti pengendalian internal tidak memperkuat pengaruh desentralisasi terhadap kinerja manajerial meskipun arahnya sudah sesuai dengan yang diprediksikan yaitu positif $(0,006)$. Hal ini dapat dilihatdari $p$ value dari masing-masing varibel yang lebih besar dari nilai $\alpha=0,05$ dimana untuk $X$ sebesar $=0,544, M$ sebesar 0,545 serta interaksi antara $X$ dan $M$ sebesar0,522. Dari hasil analisis juga diperoleh nilai $R^{2}=0,021$ yang artinya variasi nilai kinerja manajerial ( $Y$ ) yang dapat dijelaskan persamaan regresi sebesar 2,1\% dan selebihnya yaitu sebesar 97,9\% dijelaskan oleh variabel lain diluar model regresi tersebut. Dari persamaan (2) juga menunjukkan bahwa variabel efektifitas pengendalian internal tidak bertindak sebagai variabel independen karena nilai $\mathrm{p}$ value lebih besar dari $0,05(0,733)$. Dari hasil tersebut diperoleh bahwa pada persamaan (2) $b_{3} M, b_{3}$ tidak signifikan dan persamaan (3) $b_{6} X^{*} M, b_{6}$ tidak signifikan, maka variabel $M$ yaitu efektifitas pengendalian internal merupakan homologizer moderator (Sugiono, 2004)

Selanjutnya untuk memperjelas sifat dan arah masing-masing variabel, dilakukan perhitungan matematis derivasi parsial yang hasilnya disajikan dalam bentuk grafik. Tujuannya adalah untuk mengetahui apakah pengaruh tingkat desentralisasi terhadap kinerja manajerial akan konstan sepanjang garis efektifitas pengendalian internal. Apabila konstan, maka akan memperjelas pengaruh monotonic, sebaliknya apabila tidak konstan maka akan memperlihatkan pengaruh non-monotonic, Persamaan regresi dari hasil pengujian hipotesis kedua (persamaan tiga) adalah:

$Y=68,997-1,635 X-0,137 M+0,006 X^{*} M$

Persamaan derivasi parsial-nya adalah:

$\partial \mathrm{Y} / \partial \mathrm{X}=-1,635+0,006 \mathrm{M}$

Untuk $\mathrm{M}=0$, maka $\partial \mathrm{Y} / \partial \mathrm{X}=-1,635$

Untuk $\partial \mathrm{Y} / \partial \mathrm{X}=0$, maka

$0=-1,635+0.006 \mathrm{M}$

$1,635=0,006 \mathrm{M}$ 


$$
\begin{aligned}
& M=\frac{1,635}{0.006} \\
& M=272,5
\end{aligned}
$$

\section{Gambar 2. Interaksi antara tingkat desentralisasi dengan efektifitas Pengendalian Internal mempengaruhi kinerja manajerial}

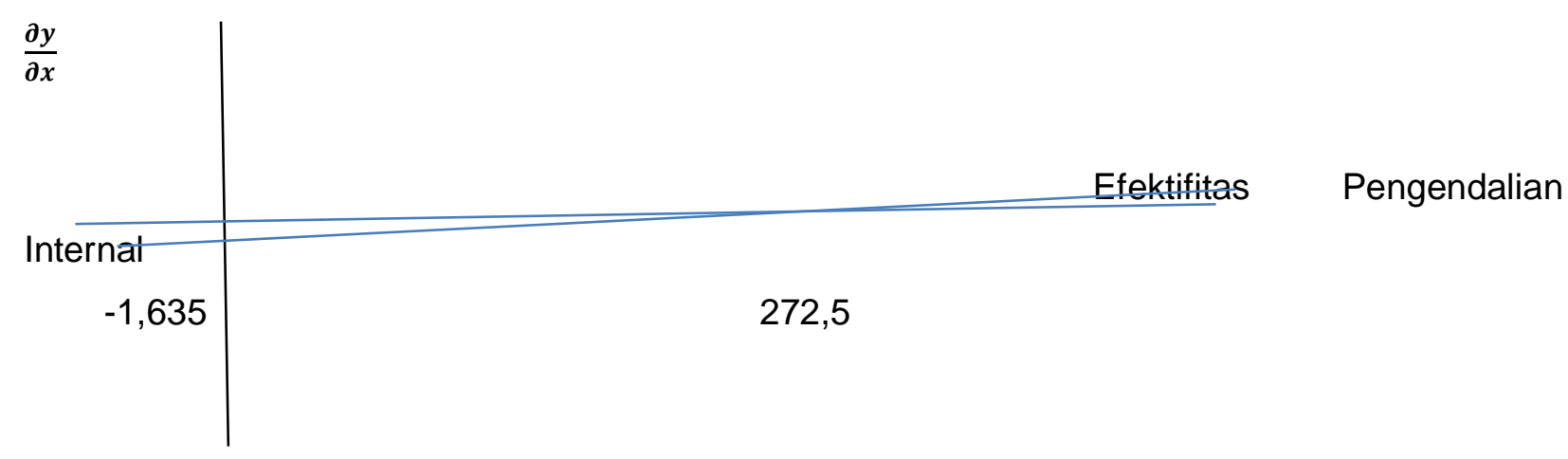

Gambar 2 menggambarkan hasil perhitungan memperjelas arah dan efek nonmonotonic dari masing-masing variabel yang berarti bahwa peningkatan pegendalian internal akan menyebabkan kenaikan kinerja manajerial dan sebaliknya apabila pengendalian internal menurun akan berakibat menurunnya kinerja manjerial. Dengan $p$ value lebih besar dari 0,05 maka hipotesis kedua yang menyatakan pengendalian internal memperkuat hubungan desentralisasi terhadap kinerja manajerial ditolak.

\subsection{Pembahasan}

Hasil pengujian regresi dengan menggunakan analisis regresi linear sederhana tidak berhasil mendukung hipotesis 1 yang berarti desentralisasi tidak berpengaruh terhadap kinerja manajerial meskipun arahnya sudah sesuai dengan yang diprediksikan. Yang dimaksud desentralisasi pada penelitian ini adalah tingkat kewenangan yang diberikan oleh Kuasa Pengguna Angaran kepada Pejabat Pembuat Komitmen dalam mengelola keuangan negara. Dengan diberikannya kewenangan dari Kuasa Pengguna Anggaran diharapkan kinerja dari masing-masing Pejabat Pembuat Komimen di Badan Pusat Statistik se Jawa Timur dapat meningkat oleh karena mereka dapat mengelola keuangan sesuai dengan tujuan dan sasaran Badan Pusat Statistik. Hasil penelitian menunjukkan desentralisasi tidak berpengaruh terhadap kinerja manajerial dalam hal ini adalah Pejabat Pembuat Komitmen. Hasil ini dikarenakan desentralisasi dalam instansi pemerintah seperti halnya pada Badan Pusat Statistik, dibatasi oleh sebuah peraturan. Meskipun Pejabat Pembuat Komitmen mempunyai kewenangan dalam mengelola keuangan negara misalnya pengambilan keputusan sehubungan dengan 
pengeluaran anggaran, pergeseran dana, rencana pencairan dana serta dalam rangka pelaksanaan pengadaan barang dan jasa, mereka harus taat pada mekanisme atau peraturan yang berlaku pada saat itu. Salah satu kasus yang biasa terjadi di Badan Pusat Statistik adalah masalah pergeseran dana. Penyediaan dana dalam Daftar Isian Pelaksanaan Angaran (DIPA) seringkali tidak sesuai realisasi kebutuhan di lapangan sehingga satker Badan Pusat Staistik se Jawa Timur pasti akan melakukan revisi DIPA. Dalam proses revisi DIPA ini Pejabat Pembuat Komitmen tidak serta merta menggeser dana yang berlebih untuk digabung dengan kegiatan yang lain atau menciptakan sub kegiatan baru dengan tujuan agar dana yang berlebih tersebut dapat diserap dengan maksimal. Akan tetapi proses pergeseran dana harus mengacu pada Peraturan Menteri Keuangan yang mengatur tentang revisi anggaran yaitu PMK No. 257/PMK.02/2014. Dalam PMK tersebut mengatur bahwa pergeseran harus berada dalam satu keluaran (output) satu kegiatan dan satu satuan kerja. Selain itu dana dari belanja pegawai tidak boleh digeser ke belanja barang atau belanja modal. Meskipun pergeseran dana dapat dlakukan sendiri oeh tiap-tiap Pejabat Pembuat Komitmen se Jawa Timur, namun mereka tetap harus laporan sebelum dan sesudah melakukan pergeseran dana ke BPS Provinsi Jawa cq sub bagian Bina Program agar terjadi keseragaman anatar satuan kerja dalam hal ini Badan Pusat Statistik Kabupaten/Kota. Hal ini sesuai dengan sifat dari Badan Pusat Statistik sebagai instansi vertikal.

Hasil penelitian ini dapat didukung oleh diagram jawaban dari Pejabat Pembuat Komitmen baik yang berjenis kelamin pria atau wanita, maupun pegawai yang baru menjabat sebagai Pejabat Pembuat Komitmen atau yang sudah lama menjabat, didominasi oleh tingkat wewenang dengan pertimbangan dan hanya sebagian kecil yang memberi jawaban tingkat wewenang penuh dalam rangka mengambil keputusan sehubungan dengan pengeluaran anggaran, pergeseran dana, rencana pencairan dana serta dalam rangka pelaksanaan pengadaan barang dan jasa. Hasil ini dapat dilihat dari deskriptif variabel desentralsi pada tabel 4.5 dimana rata-rata score jawaban responden terhadap variabel tingkat desentralisasi sebesar 3,75 (interval 2.6 sampai dengan 4,5) yang berarti tingkat desentralisasi pada kategori sedang (tergantung perintah atau tingkat kewenangan dengan pertimbangan) Hal ini selaras dengan konsep konvensional dari teori $\mathrm{X}$ bahwa sehubungan dengan orang, prosesnya adalah mengarahkan, memotivasi, mengendalikan dan memodifikasi perilaku mereka agar sesuai dengan dengan kebutuhan organisasi.

Hasil penelitian ini tidak sejalan dengan penelitian Hidayat (2015), Ingkiriwang (2013) dan Nadirsyah et al. (2012) akan tetapi searah dengan temuan dari Miah dan Mia (1996) oleh karena lingkup dari organisasi Badan Pusat Statistik pada tingkat Kabupaten/Kota yang relatif kecil, yang mana dapat dilihat pada struktur organisasi dengan jabatan tertinggi kepala kantor dan diikuti kepala seksi. Dan pada umumnya Pejabat Pembuat Komitmen berasal dari kepala seksi. 
Adanya mutasi pegawai terutama pejabat di lingkungan Badan Pusat Statistik se Jawa Timur yang juga berimbas pada pergantian Kuasa Pengguna Anggaran dan Pejabat Pembuat Komitmen sebagai pelaku desentralisasi dalam mengelola keuangan negara, menyebabkan hampir separuh responden yang menjabat sebagai Pejabat Pembuat Komitmen di Badan Pusat Statistik se Jawa Timur mempunyai pengalaman hanya satu tahun. Hal ini dapat dilihat pada tabel 4.2.

Hasil perhitungan regresi dengan menggunakan analisis regresi Moderated Regression Analysis (MRA) juga tidak berhasil mendukung hipotesis 2 yang berarti variabel pengendalian internal tidak memperkuat secara signifikan pengaruh desentralisasi terhadap kinerja manajerial walaupun arah dan efek interaksinya non-monototic. Hasil ini dapat terjadi oleh karena efektifitas pengendalian internal yang ada di Badan Pusat Statistik se Jawa Timur pada kategori sedang atau belum berjalan secara memadai. Rata-rata score jawaban responden terhadap efektifitas pengendalian internal sebesar 3,95 (interval 3,06 sampai dengan 4,48) yang berarti efektifitas pengendalian internal yang ada di BPS se Jawa Timur pada kategori sedang. Jika dilihat dari kelima unsur pengendalian, maka unsur penilaian risiko mempunyai nilai rata-rata yang paling rendah yaitu sebesar 3,29 . Bahkan pada unsur penilaian resiko ini mempunyai nilai minimum yang sangat rendah yaitu sebesar 1,29 yang berarti tidak pernah dilakukan penilaian risiko. Dengan hasil tersebut maka hasil penelitian ini tidak sejalan dengan penelitian Nugraha dan Astha (2016) dan Primadana et al. (2014) tetapi sejalan dengan penelitian Sawitri et al. (2015).

\section{Kesimpulan, Keterbatasan dan Saran}

\subsection{Kesimpulan}

Berdasarkan hasil perhitungan dan analisis data untuk hipotesis pertama dapat disimpulkan bahwa tingkat desentralisasi tidak berpengruh terhadap kinerja manajerial Pejabat Pembuat Komitmen Badan Pusat Statistik se Jawa Timur. Sedang untuk hipotesis kedua dapat disimpulkan bahwa efektifitas pengendalian internal bukan merupakan variabel yang memperkuat hubungan antara desentralisasi dan kinerja manajerial.

Adanya peraturan yang harus dipatuhi membuat Pejabat Pembuat Komitmen kurang leluasa dalam menjalankan kewenangan yang diberikan oleh Kuasa Pengguna Anggaran dalam mengelola keuangan negara. Daari jawaban responden untuk variabel tingkat desentralisasi,hanya sebagian kecil yang memberi jawaban tingkat wewenang penuh dalam rangka mengambil keputusan sehubungan dengan pengeluaran anggaran, pergeseran dana, rencana pencairan dana serta dalam rangka pelaksanaan pengadaan barang dan jasa. Hal ini selaras dengan konsep konvensional dari teori $X$. 
Masih adanya satu unsur pengendalian internal yaitu unsur penilaian risiko yang mempunyai rata-rata sedang berdampak pengendalian internal tidak signifikan memperkuat hubungan desentralisasi terhadap kinerja manajerial. Penelitian ini juga memberikan implikasi bahwa asih belum memadainya efektifitas pengendalian internal di Badan Pusat Statistik se Jawa Timur terutama pada unsur penilaian risiko agar menjadi perhatian bagi para pimpinan Badan Pusat Statistik dan mempertahankan atau bahkan menaikkan empat unsur yang lain.

\subsection{Keterbatasan Penelitian dan Saran}

Penelitian ini dilakukan pada Badan Pusat Statistik Se Jawa Timur dimana lingkupnya yang relatif kecil, yang mana dapat dilihat pada struktur organisasi dengan jabatan tertinggi kepala kantor dan diikuti kepala seksi. Sehingga untuk penelitian selanjutnya bisa dilakukan pada Badan Pusat Statistik Provinsi se Indonesia yang lingkupnya/struktur organisasinya lebih besar.

\section{Daftar Pustaka}

Arens, A. A., Elder, R. J., dan Beasley, M. S. (2008). Auditing Dan Jasa Assurance. Jakarta: Erlangga.

Garrison, R. H., Noreen, E. W., dan Brewer, P. C. (2013). Akuntansi Manajerial. Terjemahan A. Totok Budisantoso, Se., Akt. Jakarta: Salemba Empat.

Ghozali, I. (2006). Aplikasi Analisis Multivariate Dengan Program SPSS: Badan Penerbit Universitas Diponegoro.

Hidayat, T. (2015). Pengaruh Kejelasan Sasaran Anggaran, Struktur Desentralisasi dan Locus Of Control Terhadap Kinerja Manajerial. Akuntabilitas, 8(2), 148-161.

Hill, C. W. (1988). Corporate Control Type, Strategy, Size And Financial Performance [1]. Journal Of Management Studies, 25(5), 403-417.

Ingkiriwang, O. F. (2013). Pengaruh Desentralisasi dan Sistem Akuntansi Manajemen Terhadap Kinerja Manajer Dealar Di Manado. Jurnal Riset Ekonomi, Manajemen, Bisnis Dan Akuntansi, 1(3).

Mardiasmo, A. (2002). Otonomi dan Manajemen Keuangan Daerah: Good Governance, Democratization, Local Government Financial Management: Edisi Bahasa Indonesia, Penerbit Andi, Yogyakarta.

Mcgregor, D. (1989). The Human Side Of Enterprise. Readings In Managerial Psychology, 314324.

Miah, N., dan L. Mia. (1996). Decentralization, Accounting Controls and Performance Of Government Organizations: A New Zealand Empirical Study. Financial Accountability \& Management, 12(3), 173-190.

Mulyadi, A. M. (2001). Konsep, Manfaat dan Rekayasa, Edisi Ketiga, Jakarta: Pt. Salemba Empat. 
Nadirsyah, M.R. Yahya, dan G. Putra. (2012). Faktor-Faktor Yang Mempengaruhi Kiner Ja Manajerial Satuan Kerja Perangkat Daerah (SKPD) Pada Pemerintah Kabupaten Aceh Tengah. Ekonomi Dan Pembangunan, 63.

Nugraha, dan T. Astha. (2016). Pengaruh Partisipasi Anggaran dan Desentralisasi Organisasi Terhadap Kinerja Manajerial Dengan Pengawasan Internal Sebagai Variabel Pemoderasi (Studi Analisis Pada Pemerintah Kabupaten Pemalang). Media Ekonomi Dan Manajemen, 30(1).

Otley, D. T. (1980). The Contingency Theory Of Management Accounting: Achievement and Prognosis. Accounting, Organizations And Society, 5(4), 413-428.

Primadana, G. H. M., G.A. Yuniarta, dan I.M.P. Adiputra. (2014). Pengaruh Partisipasi Dalam Penyusunan Anggaran, Kejelasan Sasaran Anggaran dan Struktur Desentralisasi Terhadap Kinerja Manajerial SKPD Dengan Pengawasan Internal Sebagai Variabel Pemoderasi (Studi Empiris Pada Pemerintah Kabupaten Badung). Jimat (Jurnal Ilmiah Mahasiswa Akuntansi S1), 2(1).

Sugiono, S. (2004). Konsep, Identifikasi, Alat Analisis dan Masalah Penggunaan Variabel Moderator. Jurnal Studi Manajemen Organisasi, 1(2), 61-70. 